\title{
SNP PARK2-e01 (-2599) Polymorphism PARK2 Gene As A Risk Factor Caused Leprosy
}

\author{
Qaira Anum ${ }^{1}$, Eryati Darwin ${ }^{2}$, Sri Linuwih ${ }^{3}$, Djong Hon Tjong ${ }^{4}$ \\ \{qairaanuma@yahoo.com¹, eryatidarwin@fk.unand.ac.id ${ }^{2}$, susetyo_mr@yahoo.com³ \\ Tjong20@yahoo.com $\left.{ }^{4}\right\}$ \\ Dermatology and Venereology Departement of Dr. M Djamil Hospital/Medical Faculty of Andalas \\ University, Padang, Indonesia ${ }^{1}$ \\ Histology Departement, Faculty of Andalas University, Dermatology and Venereology Departement \\ of Dr. Ciptomangunkusumo Hospital/Medical Faculty of Indonesia University, Jakarta, Indonesia ${ }^{3}$ \\ Biology Department, Faculty of Mathematics And Natural Science Andalas University ${ }^{4}$
}

\begin{abstract}
Genetic factor is important in determining a person to get leprosy. Genes that affect susceptibility to Mycobacterium Leprae are SNP PARK2-e01 (-2599) PARK2 genes. These genes act as phagocytosis in macrophages in a non-specific immune process. This study aims to prove that there are SNP PARK2-e01 (-2599) PARK2 genes in leprosy and household contact patients. SNP PARK2-e01 (-2599) PARK2 genes were analyzed in 60 individual with leprosy or household contact from West Sumatera. The purpose of this study was to prove the SNP PARK2-e01(-2599) PARK2 gene in leprosy and household contact patients. This research method is observational research with cross-sectional comparative study design, by comparing SNP PARK2-e01 (-2599). The results of this study obtained the most aged in leprosy patients was 12-16 years and household contact aged was 36-45 years $(\mathrm{p}=0.293)$. The leprosy patients group who had SNP PARK2-e01 $(-2599)$ polymorphism PARK2 gene was $90 \%$ while in household contact was $83.3 \%$. Statistical test results obtained $\mathrm{p}=0.75$ with $\mathrm{OR}=1.8$ (95\% CI $0.389-8.323)$. The conclusion proved he was an SNP PARK2-e01 (-2599) PARK2 gene in leprosy and household contact patients.
\end{abstract}

Keywords: Leprosy, Polymorphism PARK2 Gen, SNP PARK2-e01 (-2599).

\section{Introduction}

Leprosy is one of the eight neglected tropical diseases that still exist in Indonesia, so the disease continues and becomes a public health problem in Indonesia. WHO data in 2014 reports Southeast Asia is the highest prevalence of leprosy in the world, at 0.68 per 10,000 population. Indonesia is the third-ranked in the world with the most recent cases after India (134,752 cases) and Brazil (33,307 cases). In Indonesia, most new leprosy cases (high endemic) was in eastern Indonesia (Papua, Maluku, Sulawesi). Sumatra, except Aceh which is low endemic, however, new cases of leprosy continue to exist annually.[1],[2],[3]

Research to identify genetic risk factors of leprosy has been widely practiced in various endemic areas. Some genes have been identified, including VDR, HLADR2, TAP1 and TAP2, CTLA4, COL 3A, SLC ILA1 (NRAMP1), IL-10, and TNF- $\alpha$. The genes generally found are associated with the role of natural immunity and the recognition of bacteria at the onset of infection. While the gene associated with acquired immunity is a gene PARK2 [4],[5]. One of 
the genes that affect natural resistance to M. leprae is the PARK2 gene. PARK2 is a common risk factor for leprosy. Scollard (2006) study on leprosy patients population in Brazil, obtained specific loci on PARK2 gene promoter located on chromosome 6q25-q27. The PARK2 gene is expressed in Schwan cells (SC) and monocyte-derived macrophages, which support ubiquitinmediated proteolysis through biochemical pathways, play an important role in controlling M. leprae infection. Watt's (2004) and Muller (2004) studies have also proven the mechanism through ubiquitin-proteasome pathways in intracellular protein degradation within the macrophages. Furthermore, these conditions affect the presentation of the antigen against lymphocytes and produce an immune response.[6] Although the exact mechanism of this PARK2 gene in influencing leprosy susceptibility remains uncertain, the data above support an important role of the PARK2 gene in neurologic disease and infection.

Leprosy in West Sumatra continues to exist, although the government has programmed multidrug therapy (MDT). It is possible whether PARK2 gene polymorphism is a risk factor for leprosy in areas with low endemicity.

\section{Materials and Methods}

This research is observational research with cross-sectional comparative study design, a consecutive sampling of leprosy patient and household contacts came to Outpatient Clinic of Dermatology and Venereology Departement, Dr. M. Djamil hospital Padang, Public Health Center of Padang Pariaman, Pariaman city and Limapuluh Kota district of West Sumatera during 2015 to 2017. The subjects are 30 patients leprosy, control 30 household contact. The research stages are sample collection, DNA isolation, primary design for SNP, RFLP-PCR, PCR direct sequencing method and analysis with SPSS. And also to analyze the correlation of SNP PARK2-e01 (-2599) PARK2 gene as leprosy risk factor between the leprosy patients group and the control group. In addition to using the RFLP-PCR method to recognize SNP PARK2-e01 (2599), also used the direct DNA sequencing method so that alleles are visible. The results of the sample sequencing on the PARK2-e01 SNP (-2599) PARK2 gene were analyzed bioinformatically with contig and BLAST (Basic Local Alignment Search Tool). To tidy the sequenced data is done contig by using Genious.

\section{Results}

The results of the study obtained the most aged patient's leprosy was 12-16 years, and household contacts aged was $36-45$ years $(\mathrm{p}=0.293)$. Electrophoresis is done by taking several samples in leprosy patients and household contact. Examples of some samples of PCR SNP PARK2-e01 (-2599) products which were electrophoresed, visualized with RFLP-PCR SNP PARK2-e01 (-2599) electrophoregram can be seen in Fig. 1. 


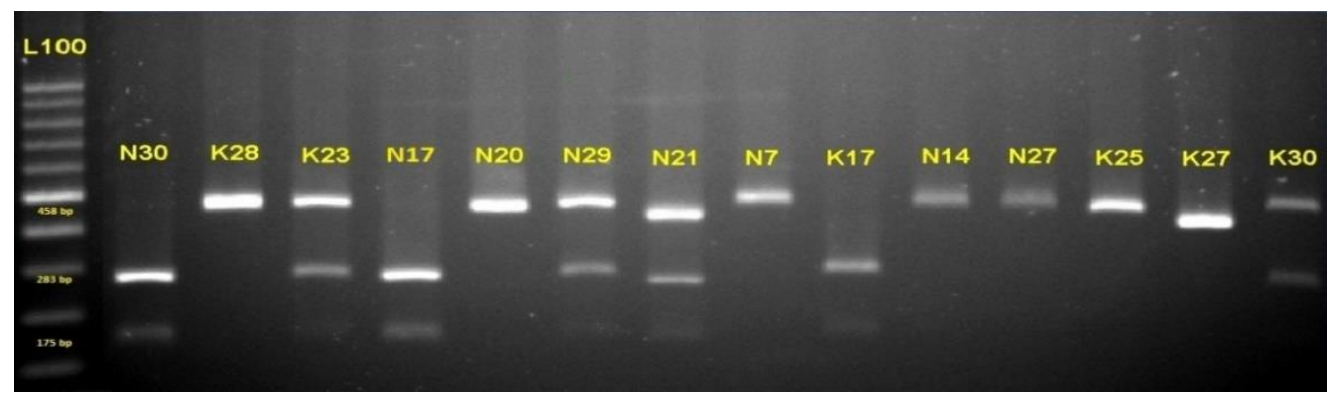

Fig. 1. Electropherogramresults of PCR SNP PARK2-e01(2599).

According to figure 1, the success of RFLP-PCR SNP PARK2-e01 (-2599) that showed with $175 \mathrm{bp}$ DNA band fragment and $283 \mathrm{bp}$. Polymorphism/homozygote mutants if there is a 458 bp DNA band fragment (one band DNA). Polymorphism/heterozygote mutants also occur when there is a required DNA fragment of $458 \mathrm{bp}, 283 \mathrm{bp}$ and $175 \mathrm{bp}$ (3 DNA bands) as K23, K30, N21, and N29. Polymorphism does not occur if there are two fragments of $283 \mathrm{bp}$ and $175 \mathrm{bp}$ DNA bands called the Wild Types.

Results of RFLP-PCR in leprosy patients group found SNP PARK2-e01 (-2599) polymorphisms as much as $90 \%$. Statistical analysis was found to be insignificant ( $\mathrm{p}>0.05)$ while in household contact group obtained polymorphism $83.2 \%$. In the leprosy group, the SNP PARK2-e01 (-2599) polymorphism was seen in samples K23, K25, K27, K28, and K30. Polymorphism is also found in the group of household contact on samples N14, N20, N21, N27, and N29.

The result of data analysis of polymorphism correlation between SNP PARK2-e01 (-2599) PARK2 gene with leprosy incidence can be seen in table 1.

Table 1. The correlation between SNP PARK2-e01(-2599) with leprosy incidence.

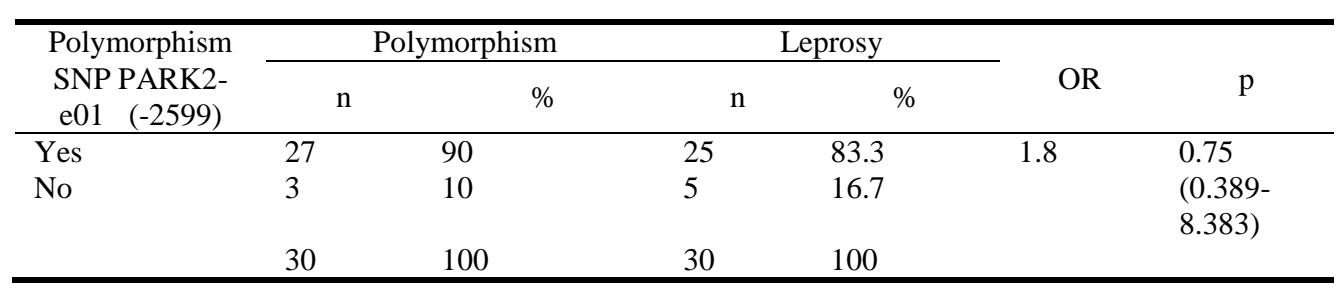

According to table 1, in the leprosy patients group, 27 (90\%) had SNP PARK2-e01 (-2599) PARK2 polymorphism gene only 3 (10\%) cases did not have SNP PARK2-e01 (-2599) PARK2 polymorphism gene. Meanwhile, the group of household contact with SNP PARK2-e01 (-2599) polymorphic gene was $25(83.3 \%)$. Statistical test results obtained $p$-value $=0.75$ with the value $\mathrm{OR}=1.8$ (95\% confidence interval $0.389-8.323$ ). There is a difference of proportion between the leprosy patients group and the household contact group with the presence of polymorphism SNP PARK2-e01 (-2599). 


\section{Discussion}

This study shows that the largest age group of leprosy patients is $12-16$ years $(26.7 \%)$. This suggests that leprosy patients are exposed at a younger age. Thorat (2010) studies that leprosy can occur at any age but often occur in the age group between 20-30 years. Leprosy incidence is more common among adults than among younger individuals. This is caused by a leprosy infection that can occur throughout the age or incubation period of the old M. leprae that is 320 years.[7]

Subjects that do not work seem more, both in groups of leprosy patients or household contact. This is due to the activity of the study subject as a housewife or student. Occupations that are at risk for contracting leprosy infection are those that work in contact with others and are in a humid environment. By the study by Mankar (2011) found that leprosy is commonly found in farmers.[8]

According to the history of contact with leprosy patients previously found only $9 \%$ proved to have household contact with leprosy patients. Most of the study subjects did not know whether they were in contact with leprosy patients or not. This is due to the clinical picture of a great imitator or asymptomatic leprosy (subclinical leprosy) so that patients are not aware of any leprosy process in the body. There is a stigma in society so that patients hide the pain, including the family. So many individuals in this case household contact not know any family members are sick.

In this study, BCG vaccination in leprosy group was only $36.6 \%$, in contrast to a household contact group reaching $83.3 \%$. It is likely that BCG vaccination is useful to protect the household contact, so it does not hurt. Research Zenha et al supports this., (2010) proves that vaccination can be as leprosy protection around $20-80 \%$. The rates of protection against BCG vaccination vary greatly among different populations.[9] Another possibility is that the infected household contact but did not appear clinically (subclinical leprosy).

In this study, the most common classification of leprosy was PB type leprosy (66.7\%) and more negative BI results. In contrast to Shen's (2009) study, the MB leprosy ratio is: PB is 3.20.[10] This suggests that the immune status of leprosy patients in this study is good especially the cellular immunity system. Thus, patients infected with M.leprae germs exhibit clinical manifestations of PB type leprosy. The clinical manifestations of leprosy result from the host response to M.leprae or the accumulation of bacterial counts. In PB type leprosy the most important role of immune response is cellular immunity, otherwise, in MB type leprosy, the role of immune response is humoral immunity.

In this study, we can see that there is polymorphism of SNP PARK2-e01 (-2599) PARK2 gene in leprosy patients $27(90 \%)$ and $25(83.3 \%)$ in leprosy. From the results of statistical tests obtained $\mathrm{p}$ value $>0.05$, meaning there is a no significant difference between leprosy patients with household contact, $\mathrm{OR}=1,8$ (95\% confidence interval $0.389-8.323)$. This is due to the presence of PARK2 SNP PARK2-e01 (-2599) PARK2 gene polymorphisms in both leprosy and household contact patients. It is assumed that household contacts who have PARK2 gene will have the predisposition to get leprosy because they might already get subclinical leprosy (with no leprosy lesion).

In this study, the frequency of $\mathrm{T}$ allele in leprosy is higher $(71,6 \%)$ than household contact $(28 \%)$ whereas the frequency of $\mathrm{C}$ alleles in leprosy is $65 \%$ and $35 \%$. Polymorphism homozygote SNP PARK2-e01 (-259) in more leprosy patients $(53.3 \%)$ than heterozygous polymorphism (36.6\%) so it is assumed to be a more high occurrence of clinical symptoms. This is also proved in the household contact group, homozygous polymorphism SNP PARK2-e01 ($2599)$ higher $(46.6 \%)$ than with heterozygotes $(36.7 \%)$. Mira et al.'s research supports the role 
of polymorphism SNP PARK2-e01 (-2599) T alleles in the PARK2 region as common risk factors for leprosy symptoms.

The PARK2 gene as phagocytosis in macrophages is a non-specific immune process. In the macrophages there is protein degradation, thus disrupting the presentation of antigens into lymphocytes (Watt, 2004). Bakijo's (2011) study on leprosy patients found that polymorphism of SNP PARK-e01, position -2599 was associated with leprosy occurrence found in 2 different ethnicities in Vietnam $(p=0,0006)$ and Brazil $(p=0.0003)$. However, this study is inconsistent with studies in India in 2006 and China in 2011 that show no correlation between PARK2 SNP PARK2-e01 (-2599) gene with risk factors for susceptibility to leprosy. Possible other SNPs affect the occurrence of unexamined leprosy. According to Schurr (2006) that individuals who are frequently exposed to $\mathrm{M}$. leprae will have an infection of genes that have the PARK2 gene, there will be MB or PB type leprosy or no leprosy.[4],[10]

This study has a limitation because we did not compare SNP PARK2-e01 (-2599) PARK2 polymorphism gene with a subject that did not expose with leprosy. We also only study 1 SNP on the PARK2 gene only, while there are many SNP and gene assumed to have relation with leprosy. Even though, someone with household contact who have SNP PARK2-e01 (-2599) PARK2 polymorphism gene is suggested to followed up by a health provider and to improve healthy lifestyle to make an early diagnosis of leprosy.

\section{Conclusions}

According to the results of this study, it can be concluded that: (1) There SNP PARK2-e01 (-2599) PARK2 polymorphism gene in leprosy patients and household contact; (2) SNP PARK2-e01 (-2599) PARK2 polymorphism gene is associated with susceptibility predisposition of leprosy.

\section{References}

[1] Bhat RM, Prakash C. Leprosy: An overview of pathophysiology. Interdiscip Perspect Infect Dis. Vol. 2, pp. 1-6 (2012).

[2] KementerianKesehatanRepublik Indonesia. Pedoman nasional program pengendalian penyakit kusta. Jakarta (2014).

[3] KementerianKesehatanRepublik Indonesia. ProfilKesehatan Indonesia 2015.Jakarta (2016).

[4] Bakijo-Kansuo A, Mulic R, Boraska V, et al. Leprosy epidemic during history increased protective allel frequency of PARK2/PACRG genes in the population of the Mljed Island, Croatia.EJMG. vol. 54. pp. 548-52 (2011).

[5] Orlova M, Pietrantonia T, Schurr E. Genetic of infections diseases: Hidden etiologies and common pathways. ClinChem Lab Med. Vol. 49. pp. 1427-37 (2011).

[6] Scollard D. The biology of nerve injury in leprosy (Review). Lepr Rev. Vol. 79. pp. 242-53(2008).

[7] Thorat DM and Sharma P. Epidemiology. In: IAL Textbook of Leprosy, 1st edn (Kar HK, Kumar B, eds), Jaypee Brothers Medical Publishers,New Delhi. pp. 24-31(2010).

[8] Mankar JM, Joshi SM, Velankar DH, Mhatre RK, Nalgunwar AN. A comparative study of the quality of life, knowledge, attitude and belief about leprosy disease among leprosy patients and community members in Shantivan Leprosy Rehabilitation Centre, 
Nere, Maharastra, India. Journal of Global Infectious Diseases. Vol 3. pp. 378382(2011)

[9] Moraes MO, Cardoso CC, Vanderborght PR, Pacheco AG. Genetic of host response in leprosy. Lepr Rev. Vol. 77. pp. 189-202 (2006).

[10] Schurr E, Alcais A, De Leseleuc L, Abel L. Genetic predisposition to leprosy: A major gene reveals novel pathway of immunity to M. leprae. SemnImmunol. Vol. 18. pp. 404-10(2001). 